\title{
Genetics of two marine shrimp hatcheries of the Pacific white shrimp Litopenaeus vannamei (Boone, 1931) in Pernambuco, Brazil
}

\author{
Genética de duas larviculturas de camarão branco do Pacífico Litopenaeus vannamei \\ (Boone, 1931) em Pernambuco, Brasil
}

\author{
Ana Patrícia Souza de Lima ${ }^{\mathrm{I}}$ Suzianny Maria Bezerra Cabral da Silva ${ }^{\mathrm{I}}$ \\ Karine Kelly Cavalcanti Oliveira ${ }^{\mathrm{I}}$ Rodrigo Maggioni $^{\mathrm{II}}$ Maria Raquel Moura Coimbra ${ }^{\mathrm{I}}$
}

\section{ABSTRACT}

The shrimp industry has grown significantly over the past 10 years in Brazil, especially the farmed production of the exotic Pacific white shrimp, Litopenaeus vannamei. In 2004, this industry was marked by a productivity crisis, which stirred interest towards genetic improvement of shrimp stocks. Shrimp breeders importation was banned in Brazil by a govern Normative Instruction in 1997, as a sanitary precaution. Since then, broodstock replacement in hatcheries has been based on domestic stocks, raising concerns on the decline of genetic diversity and if the existing diversity would allow effective genetic improvement programs. In the present research, genetic parameters such as number of alleles, effective allele number, expected and observed heterozygosities, inbreeding coefficient, genetic differentiation index and deviation from HardyWeinberg equilibrium have estimated of two important commercial hatcheries in Northeast Brazil, genotyping 5 microsatellite loci. Effective allele number (3 to 10.5) and average observed and expected heterozygosities (0.480 and 0.680 ) were consistent with those reported for cultured and wild Penaeid populations. However, $F_{I S}$ positive values ( 0.381 for hatchery A and 0.249 for hatchery B) reflected a significant heterozygous deficiency within hatcheries $(P<0.01)$. Nevertheless, we concluded that even after ten years of limited genetic input, it has been possible to maintain a high level of genetic variability, possibly due to the wide diverse origin of the founder broodstocks and the constant breeders exchange among hatcheries.

Key words: Litopenaeus vannamei, population genetics, genetic diversity, microsatellite.

\section{RESUMO}

A carcinicultura cresceu significativamente no Brasil ao longo dos últimos 10 anos, especialmente a produção do camarão branco do Pacífico, o exótico Litopenaeus vannamei. Em 2004, a atividade foi marcada por uma crise na produção, que despertou interesse na implantação de programas de melhoramento dos estoques de camarão. A importação de crustáceos foi banida do Brasil por uma Instrução Normativa de 1997, como uma medida de precaução sanitária. Desde então, a reposição de matrizes nas larviculturas passou a ser conduzida com estoques domesticados, gerando preocupações sobre o possível declínio da diversidade genética e sobre a possibilidade de que a diversidade genética existente pudesse garantir ganhos efetivos em programas de melhoramento. No presente trabalho, parâmetros genéticos, tais como número de alelos, número de alelos efetivos, heterozigosidade esperada e observada, coeficiente de consanguinidade, coeficiente de diferenciação genética $e$ desvio do equilíbrio de Hardy-Weinberg, foram estimados para duas importantes larviculturas comerciais do Nordeste do Brasil, por meio da genotipagem de cinco marcadores microssatélites. O número de alelos efetivos (3 a 10,5) e as heterozigosidades médias observada e esperada $(0,480$ e 0,680) foram consistentes com aqueles relatados para populações de peneídeos de cativeiro e selvagens. Entretanto, valores positivos de $F_{\text {IS }}(0,381$ para a larvicultura A e de 0,249 para a larvicultura B) mostraram uma deficiência significativa de heterozigotos $(P<0,01)$. Apesar disso, é possível concluir que, mesmo após 10 anos de proibição na importação de crustáceos, tem sido possível manter um alto nível de variabilidade genética, possivelmente devido a origens múltiplas do estoque de fundadores dessa espécie no Brasil e da constante troca de reprodutores entre larviculturas.

Palavras-chave: Litopenaeus vannamei, genética de populações, diversidade genética, microssatélite.

\footnotetext{
'Departamento de Pesca e Aquicultura, Universidade Federal Rural de Pernambuco (UFRPE), Rua Dom Manoel de Medeiros, s/n, Dois Irmãos, 52171-900, Recife, PE, Brasil. E-mail: raquel@depaq.ufrpe.br. *Autor para correspondência.

"Faculdade de Educação Ciências e Letras do Sertão Central, Universidade Estadual do Ceará (UECE), Quixadá, CE, Brasil.
} 


\section{INTRODUCTION}

There has been a remarkable growth in aquaculture in Brazil, especially the shrimp industry, with the introduction in the eighties of the Pacific white shrimp Litopenaeus vannamei (Penaeidea) due to the desired farming characteristics and market prince. This shrimp accounts for $99 \%$ of the shrimp production in Brazil, being the northeast region responsible for $92 \%$ of the Brazilian production (http:// www.mercadodapesca.com.br/noticias2.php?id=3063). According to FAO (Food and Agriculture Organization) data (2005), shrimp farming in 2003 yielded a total of $1,278,363$ tons globally and $40 \%$ of which was the Pacific white shrimp, native to the eastern Pacific from Sonora in Mexico to northern Peru.

In 2004, Brazilian shrimp industry was marked by a crisis due to international issues, such as the surcharge imposed on the Brazilian shrimp exported to US, increased L. vannamei production in Asia and unfavorable US dollar exchange rates. In addition, the industry has been heavily affected by viral outbreaks such as of Infectious myonecrosis virus (IMNV).

Increased susceptibility to diseases and reduced growth may be the consequence of low levels of genetic variability (WOLFUS et al., 1997). Genetic variability can ensure the fitness of a species or population by giving the species or population the ability to adapt to changing environments (DUNHAM, 2004). Farm stocks usually are derived from a small number of individuals and genetic variability may be lost not only during the founding event, but also along subsequent generations, when the population remains small and genetic exchange with other populations is minimal (RICHARDS, 2000). Therefore, unlike wild populations, cultured animals generally exhibit lower levels of genetic variability (NEI, 1978). Loss of genetic variability in shrimp aquaculture systems, as assessed by highly polymorphic, co-dominant microsatellite markers, has been described for Penaeus stylirostris (BIERNE et al., 2000), Penaeus monodon (XU et al., 2001), and L. vannamei in Ecuador and Mexico (GARCIA et al., 1994; WOLFUS et al., 1997).

To address the risk of such species being a vector for pathogenic organisms in Brazil, breeders importations were banned by a govern Normative Instruction from October 17, 1997 (MAPA, 2001). Since then, broodstock replacements in hatcheries have been based on domesticated animals, which has raised concerns about levels of genetic variability in the country, and if the remaining variability would allow effective genetic improvement programs.
Many types of molecular markers have been used to analyses the genetic parameters of natural and cultured populations; however, DNA microsatellites are quickly becoming a standard for their highly desirable characteristics of reproducibility, polymorphism and co-dominance (SCHLÖTTERER, 2000). In addition, microsatellites are highly abundant and different loci can be alternatively selectively neutral or linked to traits of interest, making this class of marker suitable for a range of applications in aquaculture.

In this context, the aim of this study was to genetically characterize two L. vannamei stocks from hatcheries located in the state of Pernambuco (northeast Brazil) through the use of microsatellites.

\section{MATERIAL AND METHODS}

Sampling

Tissue samples were randomly selected from breeders of two L. vannamei hatcheries located in the state of Pernambuco (Brazil), which account for the fourth largest shrimp exporter in the country (ROCHA et al., 2004). One hundred breeders were randomly selected from hatchery $\mathrm{A}(\mathrm{N}=50.25$ males and 25 females $)$ and $\mathrm{B}(\mathrm{N}=50.25$ males and 25 females). In order to not compromise breeders survival, only the $5^{\text {th }}$ pair of pleopods was removed and immediately stored in $95 \%$ ethanol for tissue analysis.

\section{DNA Extraction}

Tissues were crushed and digested in $0.5 \mathrm{ml}$ of $0.1 \mathrm{M}$ Tris- $\mathrm{HCl}(\mathrm{pH} 7.5), 1 \%$ SDS and $100 \mu \mathrm{g} \mathrm{ml}^{-1}$ Proteinase K, according to LIMA et al. (2008). The mixture was initially incubated at $50^{\circ} \mathrm{C}$ for $2 \mathrm{~h}$, then overnight, at $37^{\circ} \mathrm{C}$. After protein digestion, aqueous phase was extracted twice with phenol/chloroform/ isoamyl alcohol (25:24:1) and once with chloroform/ isoamyl alcohol (24:1). DNA was precipitated using ethanol; pellets were washed in 70\% ethanol, air dried and then eluted in TE (Tris-HCl 10mM pH 8.0, EDTA $1 \mathrm{mM} \mathrm{pH} \mathrm{8.0)} \mathrm{and} \mathrm{stored} \mathrm{in}-20^{\circ} \mathrm{C}$.

\section{PCRAmplification}

Five pairs of primers (Table 1) described in the literature (CRUZ et al., 2002; MEEHAN et al., 2003) were selected. The choice was based on reliability (clear bands) and polymorphism. PCR was conducted under the following conditions: denaturing at $94^{\circ} \mathrm{C}$ for $4 \mathrm{~min}$; 35 successive cycles of denaturing at $94^{\circ} \mathrm{C}$ for $30 \mathrm{~s}$, annealing at $50^{\circ} \mathrm{C}$ for $45 \mathrm{~s}$, extension at $72^{\circ} \mathrm{C}$ for $1 \mathrm{~min}$ and final extension at $72^{\circ} \mathrm{C}$ for $10 \mathrm{~min}$. Each reaction contained $1 \mathrm{U}$ Taq polymerase, $200 \mu \mathrm{M}$ each dNTP, $1 \mathrm{X}$ PCR Buffer (10mM Tris- $\mathrm{HCl}, \mathrm{pH} 8.3,50 \mathrm{mM} \mathrm{KCl}, 2.5 \mathrm{mM}$ $\left.\mathrm{MgCl}_{2}\right), 1 \mu \mathrm{M}$ each primer and $100 \mathrm{ng}$ DNA for a final volume of $10 \mu \mathrm{L}$. 
Table 1 - Microsatellite locus, forward and reverse primers and observed size (pb) for the five microsatellite loci analyzed.

\begin{tabular}{llc}
\hline Microsatellite Locus & Forward and Reverse Primers $(5, \rightarrow 3$ ') & Observed size (pb) \\
\hline TUMXLv8.2 & F: CCTCCTGTCCATTCAGCAG & $230-248$ \\
(MEEHAN et al., 2003) & R: GGTCAGATATGTATTCGAGTCGG & $166-182$ \\
TUMXLv5.27 & F: CAGACCCTAAATCTCCGTGC \\
(MEEHAN et al., 2003) & R: TGGAAAGGTCAGAGGTCACG \\
TUMXLv5.38 & F: CCTTTATGACTTCCCCCGAC & $200-222$ \\
(MEEHAN et al., 2003) & R: CCGTACAGAAACGGAACGTC \\
TUMXLv8.32 & F: TTACCGCCTAAGAGCGAATG \\
(MEEHAN et al., 2003) & R: TGTCCTTTCGTACCAGTCAAG \\
Pvan0013 & F: TGCTCTGGTAACGACAAACG & $216-228$ \\
(CRUZ et al., 2002) & R: AGACCTGTGGCGAAGTGC & $276-284$ \\
\hline
\end{tabular}

Electrophoresis and staining

The PCR products were separated through electrophoresis in a vertical polyacrylamide gel at $4 \%$ or $5 \%$, depending on the size of the expected fragment. Allele bands were detected by silver nitrate staining and imaging was performed with a digital flatbed scanner (HP Scanner 3770). For allele sizing a subset of samples containing all alleles observed for each locus was genotyped on an ABI 3100 Automated Sequencer and analyzed through GeneMapper ${ }^{\circledR}$ V 3.7 software (Applied Biosystems USA) in order to confirm and standardize allele sizes.

\section{Statistical analysis}

Statistical analyses were carried out through GENEPOP software (RAYMOND \& ROUSSET, 1995). Number of alleles (A), observed $\left(\mathrm{H}_{o}\right)$ and expected $\left(\mathrm{H}_{e}\right)$ heterozygosities and inbreeding coefficient $\left(\mathrm{F}_{I S}\right)$ were calculated as estimators of genetic diversity. Exact tests for departure from Hardy-Weinberg proportions were performed to test differences between $\mathrm{H}_{o}$ and $\mathrm{H}_{e}$, as well as for heterozygote deficiency. Genetic differentiation among populations and linkage disequilibrium were equally tested through Fisher's exact tests. All exact tests were based on Markov chains with 10.000 dememorization steps, 1.000 batches and 10.000 iterations per batch. Significance of multiple tests has been corrected by the Bonferroni method (RICE, 1989). Effective number of alleles $\left(a_{e}\right)$ was calculated by $\mathrm{a}_{e}=1 / \Sigma \mathrm{x}^{\mathrm{i}}$, where $\mathrm{xi}$ is the frequency of each allele per locus (CROW \& KIMURA, 1970). Polymorphism information content (PIC) is an indicator of marker quality in genetic studies and was calculated with the following formula described by BOTSTEIN et al. (1980):

$$
\text { PIC }=1-\left(\sum_{i=1}^{k} x_{i}^{2}\right)-\sum_{i=1}^{k-1} \sum_{j=i+1}^{k} 2 x_{i}^{2} x_{j}^{2}
$$

Where $\mathrm{K}=$ number of alleles; $\mathrm{X}_{i}=$ relative frequency of allele $i$ in the sample; and $\mathrm{X}_{j}=$ relative frequency of allele $j$ in the sample. Analysis of molecular variance (AMOVA) was performed using Arlequin 2000 (SCHNEIDER et al., 2000) based on 1,000 permutations.

\section{RESULTS}

The genetic variability of the $\boldsymbol{L}$. vannamei estimated for the five microsatellite loci studied is shown in table 2. The number of alleles ranged from 3 to 12; the number of effective alleles $\left(\mathrm{a}_{e}\right)$ ranged from 1.64 to 7.69; observed heterozygosity $\left(\mathrm{H}_{o}\right)$ ranged from 0.143 to 0.841 and expected heterozygosity $\left(\mathrm{H}_{e}\right)$ varied from 0.377 to 0.878 . The loci that exhibited the highest number of effective alleles were TUMXLv5.38 (7.18) and TUMXLv5.27 (6.14). PIC within the hatcheries ranged from 0.36 to 0.85 (Table 2). No pairs of loci were found to be in linkage disequilibrium after Bonferroni correction, indicating that they were not in the same linkage group.

The frequency distribution and size of the alleles for the five microsatellite loci are shown in figure 1. A single locus, TUMXLv8.2, exhibited the same alleles for both hatcheries. The remaining loci shared most of the alleles in both hatcheries, but also exhibited alleles that were unique to each one, at low frequencies (Figure 1). The exact tests for genetic differentiation per locus showed significant allele frequency differences $(\mathrm{P}<0.05)$ between hatcheries for loci TUMXLv5.27, TUMXLv8.2 and TUMXLv8.32 (Figure 1) and a highly significant differentiation overall $(\mathrm{P}<0.01)$. 
Table 2 - Genetic variability for five loci in the L. vannamei populations of the two shrimp hatcheries.

\begin{tabular}{|c|c|c|c|c|c|c|}
\hline \multirow{2}{*}{ Population } & \multicolumn{6}{|c|}{------------------------------------------------------Locu } \\
\hline & TUMXLv5.27 & TUMXLv5.38 & TUMXLv8.2 & TUMXLv8.32 & Pvan0013 & Average \\
\hline \multicolumn{7}{|l|}{ Hatchery A } \\
\hline $\mathrm{N}^{\circ}$ of individuals & 41 & 44 & 40 & 43 & 37 & 41 \\
\hline A & 9 & 9 & 3 & 5 & 4 & 6 \\
\hline $\mathrm{a}_{e}$ & 5.56 & 6.67 & 2.70 & 3.23 & 2.04 & 4.04 \\
\hline $\mathrm{H}_{o}$ & 0.683 & 0.773 & 0.225 & 0.395 & 0.243 & 0.464 \\
\hline $\mathrm{H}_{e}$ & 0.828 & 0.859 & 0.643 & 0.697 & 0.519 & 0.709 \\
\hline$P_{\mathrm{H}-\mathrm{W}}$ & $*$ & $*$ & $* * *$ & $* * *$ & $* * *$ & $* * *$ \\
\hline$P_{\mathrm{Ho}<\mathrm{He}}$ & n.s. & n.s. & $* * *$ & $*$ & $* *$ & $* * *$ \\
\hline PIC & 0.79 & 0.83 & 0.58 & 0.63 & 0.52 & 0.67 \\
\hline \multicolumn{7}{|l|}{ Hatchery B } \\
\hline № of individuals & 40 & 44 & 35 & 44 & 43 & 41.20 \\
\hline A & 8 & 12 & 3 & 4 & 3 & 6 \\
\hline $\mathrm{a}_{e}$ & 6.67 & 7.69 & 2.13 & 2 & 1.64 & 4.03 \\
\hline $\mathrm{H}_{o}$ & 0.725 & 0.841 & 0.143 & 0.500 & 0.279 & 0.498 \\
\hline $\mathrm{H}_{e}$ & 0.862 & 0.878 & 0.540 & 0.505 & 0.377 & 0.632 \\
\hline$P_{\mathrm{H}-\mathrm{W}}$ & $*$ & n.s. & $* * *$ & n.s. & $* * *$ & $* * *$ \\
\hline$P_{\mathrm{Ho}<\mathrm{He}}$ & $*$ & n.s. & $* * *$ & n.s. & * & $* * *$ \\
\hline PIC & 0.80 & 0.85 & 0.43 & 0.45 & 0.36 & 0.58 \\
\hline
\end{tabular}

A - number of alleles; $\mathrm{a}_{e}$ - number of effective alleles; Ho - observed heterozygosity; $\mathrm{He}$ - expected heterozygosity; $P_{\mathrm{H}-\mathrm{W}}-$ exact probability of $\mathrm{H}_{o}=\mathrm{H}_{e}$, based on 10,000 dememorization steps, 1,000 batches and 10,0000 iterations per batch; $P_{\mathrm{Ho}<\mathrm{He}}-$ exact probability associated to heterozygote deficit (Markov chain parameters as above); PIC - polymorphism information content. $* \mathrm{P}<0.05 ; * * \mathrm{P}<0.01 ; * * * \mathrm{P}<0.001 ;$ n.s., non significant.

Average $\mathrm{F}_{I S}$ values were 0.3806 for hatchery A and 0.2489 for hatchery $B$, reflecting the significant heterozygote deficiency (Tables 2 and 3). Total $F_{S T}$ was 0.0217 , indicating slight genetic differentiation (Table 3 ) and that a large part of the genetic variability was due to intra-population variation. This was confirmed by the analysis of molecular variance (AMOVA), which attributed only $2.1 \%$ of the variance to differences among hatcheries.

\section{DISCUSSION}

Past studies on shrimp have shown significant allelic variation for microsatellite loci between farmed and wild populations (WOLFUS et al., 1997; XU et al., 2001; BORRELL et al., 2004, LUAN et al., 2006). Heterozygosity and the number and distribution of alleles are important for variability estimations (BEARDMORE et al., 1997). The results presented in table 2 are in accordance with average heterozygosities estimates and allele numbers observed for other Penaeid species (Marsupenaeus japonicus, LUAN et al., 2006; Litopenaeus schmitti, BORRELL et al., 2004; L. vannamei, TIRADO, 2004, TAMAYO, 2006).
Nevertheless, BEARDMORE et al. (1997) also states that heterozygosity is a less sensitive measure of variability compared to the number and distribution of alleles and should be used with caution, once it is possible to obtain high values of heterozygosity with two alleles.

In this sense, VALLES-JIMENEZ et al. (2005) analyzed 137 individuals from natural populations of Mexico, Guatemala and Panama using 5 microsatellite markers, including Pvan0013. Considering the results for locus Pvan1003 only, we can observe that even though our $\mathrm{H}_{o}$ and $\mathrm{H}_{e}$ values are lower than those found by the Mexican group ( 0.317 and 0.602 , respectively), we have found 5 alleles out of the 6 previously observed (VALLES-JIMENEZ et al., 2005). Overall average $H_{o}$ for the shrimp hatcheries was significantly lower than $\mathrm{H}_{e}$ (Table 2), reflecting a noteworthy departure from Hardy-Weinberg equilibrium. This departure should be expected in captivity, where random breeding conditions and infinite population sizes are very unlikely to be found.

The PIC values found in the present study ( 0.36 to 0.85$)$ are within the expected range for this group of microsatellite markers. According to 


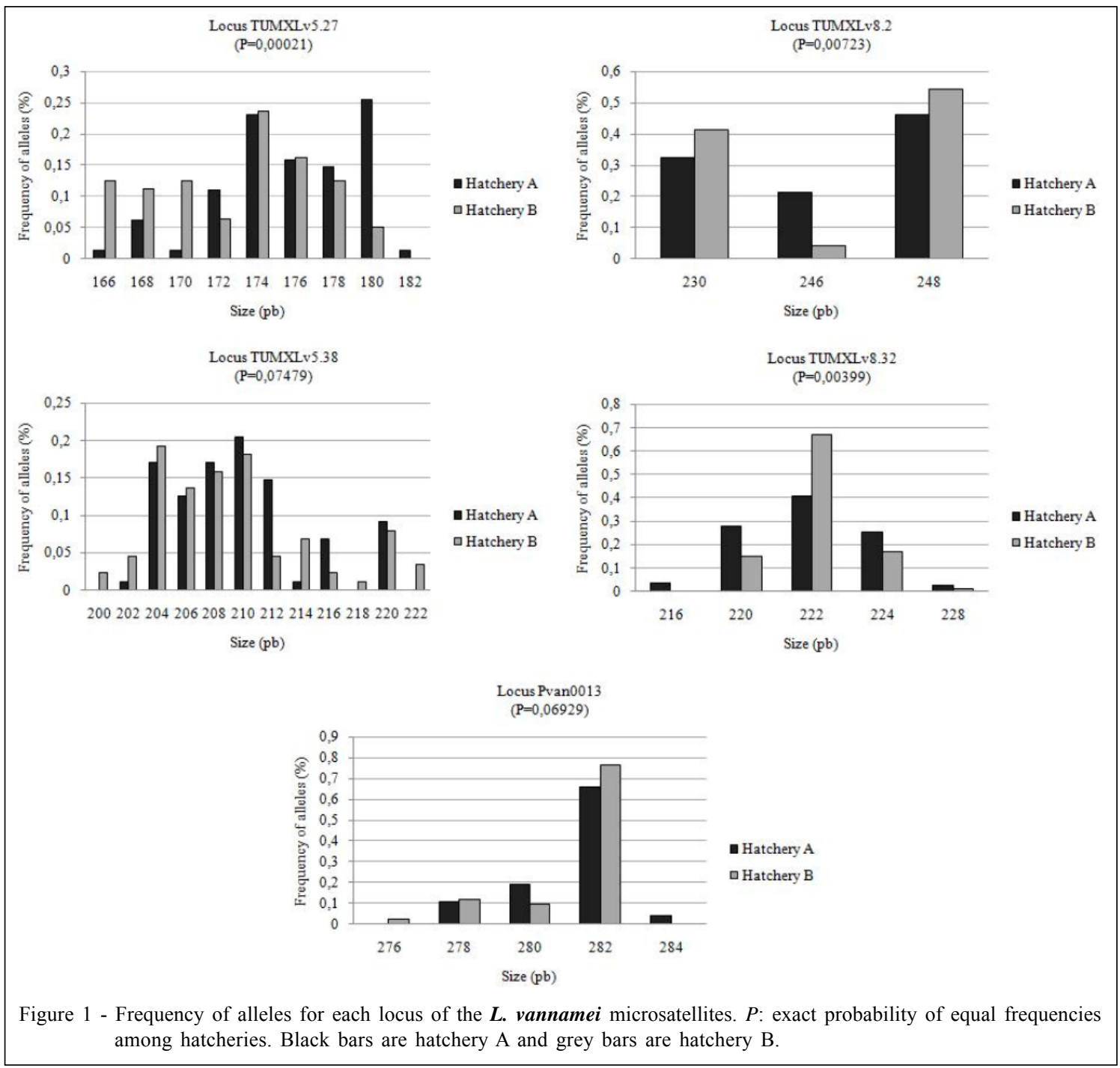

BOTSTEIN et al. (1980), markers with PIC values higher than 0.5 are considered very informative; markers with values between 0.25 and 0.50 are medially informative; and values below 0.25 are poorly informative. MEEHAN et al. (2003) described PIC values between 0.195 and 0.871 for 93 microsatellite markers, including four of the five markers assessed in the present study.

Although statistically different from zero, the genetic differences found between the two shrimp hatcheries $\left(\mathrm{F}_{S T}=0.0217\right)$ cannot be considered high. According to WRIGHT (1978), values between 0 and 0.05 indicate little genetic differentiation. LUAN et al. (2006) observed similar values $\left(\mathrm{F}_{S T}=0.023\right)$ in a comparison between wild and cultured populations of Marsupenaeus japonicus, whereas SOTOHERNANDEZ \& GRIJALVA-CHON (2004) observed higher values $\left(\mathrm{F}_{S T}=0.086\right)$ studying allozymes in wild and cultivated L. vannamei populations. The low genetic difference observed in the present study indicates that these hatcheries are likely to have accessed a founder stock of similar genetic composition. Moreover, the selection of broodstock in this kind of hatchery is usually performed in a random manner, i.e., shrimp are mass selected and transported from different grow out farms to the hatcheries, which can increase the admixture and reduce genetic differences. Analysis of molecular variance (AMOVA) reflects these reduce differences revealing that a large part of the observed variance remains in the scope of differences between individuals.

Average $\mathrm{F}_{\text {IS }}$ values were 0.38 for hatchery $\mathrm{A}$ and 0.25 for hatchery B. These values are significantly different from zero, indicating that the hatcheries may present a degree of inbreeding. Significant $\mathrm{F}_{I S}$ values have been recorded for natural populations of $\boldsymbol{L}$. vannamei in Mexico ( $\mathrm{F}_{I S}=0.53$, VALLES-JIMENEZ et 
Table 3 - Wright's Indices ${ }^{\text {a }}\left(\mathrm{F}_{I S}\right.$ and $\left.\mathrm{F}_{S T}\right)$ for the two L. vannamei shrimp hatcheries.

\begin{tabular}{llll}
\hline \multicolumn{1}{c}{ Locus } & \multicolumn{1}{c}{$\mathrm{F}_{I S}$} & \multicolumn{1}{c}{$\mathrm{F}_{I S}$} & $\mathrm{~F}_{S T}$ \\
& Hatchery A & Hatchery B & \\
\hline TUMXLv5.27 & $0.1771^{* *}$ & $0.1607^{*}$ & $0.0281 *$ \\
TUMXLv5.38 & 0.1017 & 0.0430 & 0.0006 \\
TUMXLv8.2 & $0.6532 * * *$ & $0.7381 * * *$ & 0.0132 \\
TUMXLv8.32 & $0.4360 * * *$ & 0.0105 & $0.0608 * *$ \\
Pvan0013 & $0.5352 * * *$ & $0.2921 *$ & 0.0070 \\
Average & 0.3806 & 0.2489 & 0.0217 \\
\hline
\end{tabular}

${ }^{a}$ Data from GENEPOP (RAYMOND e ROUSSET, 1995).

$* \mathrm{P}<0.05 ; * * \mathrm{P}<0.01 ; * * * \mathrm{P}<0.001$.

al., 2005), and both in wild and farmed populations $\left(\mathrm{F}_{I S}=0.63\right.$, SOTO-HERNANDEZ \& GRIJALVA-CHON 2004). The differences in $F_{I S}$ values observed between Pernambuco's hatcheries (Table 3 ) could be attributed to differences in management history and strategy, such as the number of breeding tanks, number of breeders per tack, sex proportion and broodstock selection strategy. The extent to which these variants affect inbreeding remains to be examined.

The northeastern region of Brazil has the highest shrimp farming production in the country. Limited historical records show that up to 1997 there were various shrimp imports from Mexico, Guatemala, Panama, Colombia, Ecuador and Peru (ABCC, personal communication). Apparently this diversity of origin has contributed to create a highly variable gene pool for the studied broodstocks. It seems that even after ten years of no breeder imports, it has been possible to conserve a high level of genetic variability for the Brazilian L. vannamei stocks. Continued monitoring of these hatcheries could help improving the preservation of this valuable genetic variability.

The loss of alleles can have deleterious biological consequences. For instance, it can make the stocks prone to disease (CALCAGNOTTO \& TOLEDO-FILHO, 2000).ARKUSH etal.(2002) compared the pathogen resistance of Chinook salmon with different genotypes of a gene in the major histocompatibility complex (MHC) and concluded that small wild and hatcheries populations with lowered genetic variability would have increase susceptibility to pathogens. Moreover, a level of variability such as the one observed here for the Pernambuco broodstocks of $L$. vannamei could be enough to allow a genetic improvement program aimed at the production of strains resistant to pathogens. Finally, considering the results presented here, we believe that a break on the current Brazilian live shrimp import policy, for the sake of genetic variability improvement, does not seem necessary.

\section{PERSONAL INFORMATION}

Associação Brasileira de Criadores de Camarão, Rua dos Caicós, 1865 - $1^{\circ}$ Andar Bairro: Dix Sept, 59052-700, Rosado Natal/RN.

\section{REFERENCES}

ARKUSH, K.D. et al. Resistance to three parasites in the endangered winter-run Chinook salmon (Oncorhynchus tshawytscha): effects of inbreeding and major histocompatibility genotypes. Canadian Journal of Fisheries and Aquatic Sciences, v.59, p.966-975, 2002.

BEARDMORE, J.A. et al. Biodiversity in aquatic systems in relation to aquaculture. Aquaculture Research, v.28, p.829839, 1997.

BIERNE, N. et al. Microsatellite associated heterosis in hatchery-propagated stocks of the shrimp Penaeus stylirostris. Aquaculture, v.184, p.202-219, 2000.

BORRELL, Y. et al. DNA microsatellite variability and genetic differentiation among natural populations of the Cuban white shrimp Litopenaeus schmitti. Marine Biology, v.144, p.27333, 2004.

BOTSTEIN, D. et al. Construction of a genetic linkage map in man using restriction fragment length polymorphisms. American Journal of Human Genetics, v.32, p.314-331, 1980

CALCAGNOTTO, D.; TOLEDO-FILHO, S.A. Loss of genetic variability at the transferrin locus in five hatchery stocks of tambaqui (Colossoma macropomum). Genetics and Molecular Biology, v.23, n.1, p.127-130, 2000.

CROW, J.F.; KIMURA. M. An introduction to population genetics theory. New York: Harper \& Row, 1970. 519p.

CRUZ, P. et al. Isolation and characterization of microsatellites in Pacific white shrimp Penaeus (Litopenaeus) vannamei. Molecular Ecology Notes, v.2, n.3, p.239-241, 2002.

DUNHAM, R.A. Aquaculture and fisheries biotechnology: genetic approaches. Cambridge, USA: CABI, 2004. 218p.

FAO. Aquacult-PC: fishery information, data and statistics (FIDI), time series of production from aquaculture (quantities and values) and capture fishers (quantities). Roma, 2005. (Computacional software).

GARCIA, D.K. et al. Genetic diversity of cultured Penaeus vannamei shrimp using three molecular genetic techniques. Molecular Marine Biology and Biotechnology, v.3, p.270280,1994

LIMA, A.P.S. de, et al. Genetic monitoring of broodstocks of the marine shrimp Litopenaeus vannamei in a closed rearing system in Pernambuco, Brazil. Aquaculture Research, v.39, p.1461-1466, 2008 . 
LUAN, S. et al. Genetic variation of wild and cultured populations of the Kuruma prawn Marsupenaeus japonicus (Bate, 1888) using microsatellites. Aquaculture Research, v.37, p.785-792, 2006.

MINISTÉRIO DA AGRICULTURA, PECUÁRIA E ABASTECIMENTO (MAPA). Plataforma tecnológica do camarão marinho cultivado: seguimento de mercado. Departamento de Pesca e Aqüicultura. Brasília: MAPA/SARC/ DPA, CNPq. ABCC, 2001. 276p.

MEEHAN, D. et al. High frequency and large number of polymorphic microsatellites in cultured shrimp, Litopenaeus vannamei (Crustacea, decapoda). Marine Biotechnology, v.5, p.311-330, 2003 .

NEI, M. Estimation of average heterozygosity and genetic distance from a small number of individuals. Genetics, v.89, p.583-590, 1978 .

RAYMOND, M.; ROUSSET. F. Genepop (version 1.2): population genetics software for exact tests and ecumenicism. Journal of Heredity, v.86, n.3, p.248-249, 1995.

RICE, W.R. Analyzing tables of statistical tests. Evolution, v.43, p.223-225, 1989 .

RICHARDS, C.M. Inbreeding depression and genetic rescue in a plant metapopulation. American Naturalist, v.155, p.383394,2000 .

ROCHA, I.P. et al. A carcinicultura brasileira em 2003. Revista da ABCC, v.1, p 30-36, 2004

SCHLÖTTERER, C. Evolutionary dynamics of microsatellite DNA. Journal Chromosoma, v.6, p.365-371, 2000.

SCHNEIDER, S. et al. Arlequin ver 2.000: a software for population genetics data analysis. Switzerland: Genetics and Biometry Laboratory, University of Geneva, 2000. Available from: <http://lgb.unique.ch/arlequin/software/ 2000.htm>. Accessed: Feb. 14, 2009

SOTO-HERNANDEZ, J.; GRIJALVA-CHON, J.M. Genetic differentiation in hatchery strains and wild white shrimp Penaeus (Litopenaeus) vannamei (Boone, 1931) from northwest Mexico. Aquaculture International, v.12, p.593-601, 2004.

TAMAYO, R.J.M. Assessment of genetic variability in two lots of white shrimp, Litopenaeus vannamei (Bone, 1931) introduced to Cuba. 2006. 42f. Master thesis International Fisheries Management Department of Aquatic Biosciences, Norwegian College of Fishery Science, University of Tromsø, Norway.

TIRADO, J.C.O. Desarrollo de marcadores genéticos tipo microsatélites e intrones para mapeo genético en Litopenaeus vannamei. 2004. 104f. Tesis de Magister en Ciencias - Escuela Superior Politécnica del Litoral - Facultad de Ingeniería Marítima y Ciencias del Mar, Guayaquil - Ecuador.

VALLES-JIMENEZ, R. et al. Population genetic structure of Pacific write shrimp (Litopenaeus vannamei) from Mexico to Panama: Microsatellite DNA variation. Marine Biotechnology, v.6, p.475-484, 2005.

WOLFUS, G.M., et al. Application of the microsatellite technique for analyzing genetic diversity in shrimp breeding programs. Aquaculture, v.152, p.35-47, 1997.

WRIGHT, S. Evolution and the genetics of populations. Variability within and among natural populations. Chicago: University of Chicago, 1978. V.2

XU, Z. et al. Genetic diversity of wild and cultured black tiger shrimp (Penaeus monodon) in the Philippines using microsatellites. Aquaculture, v.199, p.13-40, 2001. 